\title{
Promoting Rule of Law through Principle of Legality Challenges in the Albanian Legislation
}

\author{
Nikolin Hasani \\ Faculty of Human Sciences /Department of Law, University "Ismail Qemali” Vlorë \\ Vlorë, Albania \\ nikolin.hasani@univlora.edu.al
}

\begin{abstract}
Referring to different local sources and international one, World Bank, USAID, IMF, OSCE, Albania's respect for the rule of law is lagging behind other countries in the region. There has been significant improvement on legal standards, especially on paper, there is much too do in regard to the ability of legislation to create a system based on the principles of order and predictability and on the protection of its citizens from the arbitrary use of power.

Principle of legality is considered a core stone in forcing the state, the government, the judicial and legislative bodies to enact on retroactive legislation

The aim of this is to present the challenges in the Albanian legislation for an real and efficient rule of law as a guiding principle for organizing life in society.
\end{abstract}

Keywords: Rule of Law, Principle of Legality, Democracy, Legislation.

\section{INTRODUCTION}

The mode of the functioning of the state is defined by basic rules that are called principles. The nature of the principle is reflected to the nature of government. When the nature of the principles is democratic, the same is the government of that state. Rule of law is based in democratic principles too, and such principles have served as the basis for creation of new legislation and constitution of different countries. The rule of law in every democratic country is supported by the principle of legality, which is considering a basic principle. Convents on human rights have accepted widely this principle too.

\section{LITERATURE REVIEW}

\subsection{The Rule of Law}

Referring to the different literature review the concept of the Rule of Law is given based on the outlines that legal principles should be leading guide for the governmental decisions and that every citizen is subject to the law and nobody stands above it. International conventions extended this concept adding basic human rights, which means for the Rule of Law to be legitimate must adhere to and be in compliance with these principles of basic human rights. What is common to all different definitions that are given for the Rule of Law is the fact that when the government behavior is based on the Rule of Law, which is considered the backbone of democracy and by which people are permitted to plan their future, any conflict is resolved peacefully in the right way, citizens trust more to their government and treat each-others as member of the same society. That means, no one is above the law, government cannot punish its citizens, except in cases when guilty is proven based on legal procedures and practices, and the law. This is achieved when any public official do not act arbitrarily or violate the law. This ensures that no one person is able to gain absolute power and stand above the law. Failing to have the Rule of Law, people act so individualistic. In order to achieve this, law enforcement should not be negotiable. It should be obligatory to everyone. All the parts, government and citizens should agree that the most important part of the social contract is the obedience of all parts to the law, which by its self helps to maintain the social order.

\subsection{The Principle of Legality}

Referring to the literature review, the simple definition given for the principle of legality is that which describe it as a combination of rules according to which for an act that is not proved to be a crime, no one may be convicted and at the same time if it is proved to be a crime, no one may suffer a greater 


\section{Nikolin Hasani}

punishment than that which is foreseen by the law. Different authors gave different definitions for principle of legality. The common idea that describes these definitions is the fact that no crime or punishment can exist without a legal ground due to the fact that principle of legality is considered a core value and a fundamental defense in criminal law prosecution.

The common rules that are present at different definitions for this principle are that which prohibit a court that do not have jurisdiction over the act at the moment in which it is committed to punish someone who is responsible for this act; prohibit a court to conviction someone based on more or less evidence than could have been required at the time of the offence; the crime must be defined and notice clearly under the law before someone will be punishment for doing that; the principle of the law is applied consistently; and the last but not less important the concept that whatever is not prohibited by law is permitted.

This principle is considered a human right too. The role of this principle, nullum crimen, nulla poena sine lege, is considered very important in human liberty guaranty, protection of individuals from state abuse and unjust interference, ensuring the fairness and transparency of the judicial authority.

There are a lot of authors that consider this principle a core stone in forcing the state, the government, and the judicial and legislative bodies to enact on retroactive legislation. Going back to history, this principle was presented for the first time during the period of post-World War II. Even though the application of this principle differs among countries in Europe, the fact is that it is still common today to almost all legal systems. And the common idea is that the administrations do not take decisions that affect human rights and freedom, or impose burdens, only in cases when statutory basis is proved.

\subsection{The Rule of Law and Challenges to the Albanian Legislation}

Evident efforts to the democratization of Albania are reflected to the different field like law, media, market economy, human rights. However there are still things to be improved. This is especially true for the public sector, where administration still need to improve its performance and to fulfill adequately citizen's needs.

Corruption in different levels is another real problem. Sometimes political leadership, have lacked the will to move on to democratic reforms followed by lack of political will and lack of capacity of that part of public employees, which have been hired referring only to the political criteria. The result of this has been the poor quality of drafting and implementing of the legislation and of course has seriously affected the rule of law in Albania.

The applicable law often fails to be respected by government members, executive agencies, local governments, different political organizations, and political powerful individuals. The corruption is present at all level of society. In these conditions there are a lot of citizens that believe that law enforcement is not obligatory, it is negotiated.

There are evidence that violation of the rule of law is done first from politicians and public administration officials. There is an immediate need to develop the idea that there is no one above the law. The political and social component is the main reasons why there is such a weak rule of law. The root cause of the Albania's problem in this field is corruption. Accept the poor implementation of the law the emphasis is given to the content of certain legislation. Of course the rule of law is been undermined by the ineffective and inappropriate implementation. Sometimes the reason for this is the poor translation of European legislation or partial adoption of international models.

The rule of law has the ability to create order and predictability and to protect the citizens from arbitrary abusive use of power. The first one is achieved by restraining the action of both citizens and government and the second by division of power or setting up institutional constrains. Different analyst, local or international, suggests that in the past few years, legal standards have been improved significantly. The problem is the moment of implementation of these standards. Lustration Law is an example of this. This law was approved in 2009, and according to it extraordinary power was given to an authority of five members to decide to fire, according to an investigation, any member of the government or judiciary without due process, just based on the evidence of the investigation. There were a lot of them who criticized this law, arguing that this would have been a case for abuse by some party that have political power, resulting in political reprisal and undermine the impartiality of independent judges. This law is under review process after the suspension by the Constitutional Court. 
Another example is the law of anti-mafia. According to this law, authorities may confiscate private property of a person whose is suspected to be involved in unlawful activities. Since the procedure of confiscation is a civil one, the person whose private property is been confiscated is responsible to bring evidence to prove contrary.

There are a lot of examples of ineffective and inappropriate implementation of the law which resulted to undermine the rule of law. Sometimes this happens because of a significant barrier such as poor translation of the European laws or practices. These are called technical problems. Other technical barriers are caused by lack of facilities in implementation process. The result is a partial adoption of the European and international models, or worst; sometime it creates loopholes that have a negative impact on the overall implementation of the law.

Another reason that impedes the rule of law in Albania is lack of due processes during the legislation adaption an law application. Criticism from different interest groups has been present regarding the lack of due process in terms of which the consultations works with local stakeholders. The example for this is the law of the organization of the justice which was approved in 2008. The approval was made without the opinion of the judges. The Constitutional Courte declared some part of this law as unconstitutional.

The case of new election code, was more controversial, due to the fact that the changes to the old one were not debated within the Parliament's Commission on Electoral Reform and there was not discussed enough with the civil society and all groups of interest in the reform. Head of the OSCE Presence in Albania noticed that there was not sufficient time to discuss it with all stakeholders. This proposal was rejected by electoral commission in June 2009.

Except the fact that sometime there is not a due process in approving legislative changes or new laws in Albania, the application process of the law has been selective. The impact of this is directly reflected to the rule of law. The example for this is the lack of transparency for the media financing, even though the legislation require a full disclosure. There are a lot of them who agree that the owners of media companies just ignore the law. Or we can mention the case of law in civil service, according to which the hire process in the public administration must be merit - based only, which in the majority of cases is not applicable.

\section{CONCluding Remarks}

All the above examples lead to the conclusion that in Albania the rule of law is seriously lacking. Serious questions about the extension to which private interest have captured the state. Conflict of interest is a serious problem too.

There are a lot of examples that were individuals and organizations fail to respect the law. These groups are generally those who have politically support. Referring to others studies like those of World Bank, USAID, IMF, OSCE, there are both state and citizens who fail to compliance the law.

Even though this is not a new observation, Although this observation is not new, to make steps forward for the Albanian democracy, is very crucial to strengthen the rule of law..

\section{REFERENCES}

[1] “Albania Democracy and Governance Assessment", Revised Version, Submitted to: The U.S. Agency for International Development DCHA/DG, Under USAID Contract No. DFD-I-00-0400229-00 Democracy and Governance Analytical Services, Prepared by: Democracy International, Inc. 4802 Montgomery Lane, Suite 200, Bethesda, Maryland 20814 February 2006, p. 6.

[2] Albanian law report, year 2010 pp 23

[3] Albanian legal progress report year 2009, pp 12

[4] Albanian legal report year 2008, pp 19

[5] Amended Low No 10052, Article 17

[6] Barrolli, B. (2012). The Impact of Corruption on Rule of Law Enforcement: Evidences from Albania

[7] Bogdani, Mirela and Louglin, John, "Albanian and the European Union: The Tumultuous Journey towards Integration and Accession”, I.B. TAURIS, 2006, p. 31. 
[8] CEC (Commission of the European Communities), "Albania 2009 Progress Report", 2009, p. 6, Commission Staff Working Document, Brussels, 14.10.2009, SEC (2009) 1337.

[9] CEC, supra note 8, at 7 .

[10] Chantal Millon-Delsol, Idetë politike në shekullin e XX-të, Tiranë, Onufri, 2000, f. 243

[11] CONST. art. 136.1; LAW ON THE CONST. COURT art. 7.1

[12] Constitution, Article 146.

[13] Constitution, Article Kushtetuta , neni 145/1 and 145/3.

[14] D.Biba, Xh.Zaganjori, Implementing the rule of law in Albania, në "Political Thought", N. 32, Shkup, 2010.

[15] Decision nr. 3 date 4.9.2003.

[16] Decision nr. 31 date 29.3.2003.

[17] European Commission, Analytical Report, SEC (2010) 1335, 9 nëntor 2010.

[18] FRIDE (Fundacion para las Relaciones Internationales y el Dialogo Exterior), "Democracy Monitoring Report; Albania", 2009, p. 1.

[19] G J Simpson „War crimes: a critical introduction“e in G J Simpson \& LH Timothy The law of war crimes: national and international approaches (1997) 11.

[20] G Werle Principles of International Criminal Law (2005) 32; S Lamb, „Nullum crimen, nulla poena sinelege in international criminal lawee in A Cassese et al The Rome Statute of the International Criminal Court, Acommentary (2002) 1733.

[21] Gosalbo-Bono, R. The significance of the rule of law and its implications for the European Union and the United States. University of Pittsburgh Law review. Vol.72, pg.229 - 360.

[22] Judicial index reform in Albania, volume IV, December 2008, ISBN: 978-1-60442-454-6

[23] JUDICIAL POWER LAW art. 12.1. Members ISBN: 978-1-60442-455-3 (PDF) pp2, 8.28,48

[24] Kodit të Procedurës Penale (ligji nr. 7905, datë 21.3.1995, Low for judge article 7905

[25] Ligji nr. 8811, date 17.5.2001, 9.5.2002. "Law for Judge Power" Article 8811

[26] Ligji nr. 9087 date 19.06.2003, "Kodi Zgjedhor i Republikës së Shqipërisë.

[27] LL Fuller The morality of law (1964) 45; J Hall „Nulla Poena Sine Lege" (1938) 47 Yale Law Journal 165,171; P Westen „Two rules of legality in criminal law" (2006) 26 Law and Philosophy 231-234.

[28] Lon L. Fuller, The Morality of Law (New Haven: Yale University Press, 1969).

[29] Low no .7905, datë 21.3.1995 "Law on criminal procedure code of the Republic of Albania"

[30] Low no 8003, date 28.9.1995, ligji nr.8919, datë 4.7.2002 ("Kodi Penal Ushtarak").

[31] Low no 8588, date 15.3.2000, "Law on Judicial Power", article 135/1 point 11.12

[32] Low no 8588, date 15.3.2000. Article 11, "Law on Judicial Power"

[33] Low no 8588, date 15.3.2000. Article 13, "Law on Judicial Power"

[34] Low no 8588, date 15.3.2000. Article 19, "Law on Judicial Power"

[35] Low no 8588, date 15.3.2000. Article 20, "Law on Judicial Power"

[36] Low no. 7491, date 29.4.1991 article 42 low nr. 7491,

[37] Low no. 7561, date 29.4.1992, Low no.7491, date 29.4.1991

[38] Low no. 8436, date 28.12.1996, low no. 8546, 5.11.1999,

[39] Low no.7895, datë 27.1.1995 "For the penal law in Albania"

[40] Main Constitutional Provisions Article year 2011, Law "Për Dispozitat Kryesore Kushtetuese"

[41] Meagher, D. (2010). The common law principle of legality in the age of rights.

[42] NOSA(Network of Open Society for Albania) Report,STRATEGY on Good Governance and the Rule of Law 2006-2008, p.1.

[43] OSBE, 17.1.2003 Inspektoriatit të Këshillit të Lartë të Drejtësisë.

[44] OSCE, (Organization for Security and Co-operation in Europe),"Legal Sector Report for Albania", 2004, p. ii..

[45] OSCE, supra note 12, at ii. 
[46] Sales, P. (2010). Three challenges to the rule of law in the modern English legal system

[47] The constitution of the Albania Republic, neni 29.

[48] The constitution of the Albania Republic, neni 3.

[49] The constitution of the Albania Republic, neni 7.

[50] The decision of Supreme Court no.10, date 12.09.2007

[51] The decision of Supreme Court no.19, date 15.11.2007

[52] The Law for Supreme Court in the Republic of Albania, Article 1.

[53] The Law for Supreme Court in the Republic of Albania, Article 10-13.

[54] The Law for Supreme Court in the Republic of Albania, Article 14-17.

[55] The Law for Supreme Court in the Republic of Albania, Article 3.

[56] The Law for Supreme Court in the Republic of Albania, Article 7.

[57] Yu, Helen and Guernsey, Alison, "The Rule of Law as a Goal of Development Policy", World Bank, The Rule of Law as a Goal of Development Policy, 2006, p. 2.

[58] http://en.wikipedia.org/wiki/Rule_of_law

[59] http://en.wikipedia.org/wiki/Talk\%3ARule_of_law

\section{AUTHOR'S BIOGRAPHY}

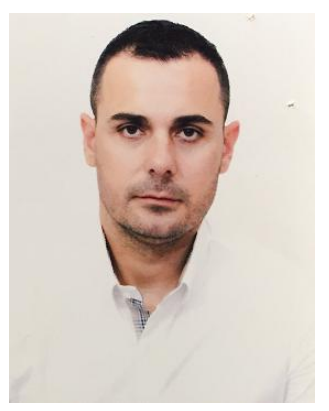

Ph.DNikolinHasani, Professor at Law Department, Faculty of Human Sciences, University "Ismail Qemali" Albania. Doctoral studies at Faculty of Law, University of Tirana, Albania. 